\title{
Well rounded Postdoctoral Researchers with initiative, who are not always "tied to the bench" are more successful academically
}

\author{
Lucy J. Lee $^{\mathrm{a}^{*}}$, Isobel Gowers ${ }^{\mathrm{b}}$, Lorraine Ellis ${ }^{\mathrm{c}}$, and Ilaria Bellantuono ${ }^{\mathrm{a}}$ \\ a Medical School, University of Sheffield, Sheffield, UK \\ ${ }^{\mathrm{b}}$ Writtle College, Chelmsford, Essex,UK \\ ${ }^{c}$ School of Health Sciences, University of Derby, Derby, UK \\ * Corresponding author. Email: L.Lee@sheffield.ac.uk
}

\begin{abstract}
This article reports the development, application and results of a baseline investigation of contract research staff in 2007 in the Medical School at the University of Sheffield which was carried out in order to develop a specifically tailored training and career development programme and allow for future impact evaluation of the scheme. Postdoctoral researchers reported on their perceived skill levels, academic achievements, career motivations and the current research environment. Results indicated that transferable skills related to communication and awareness of the process of research (i.e. the process of acquisition of funding, commercialisation of research outputs) were lacking. Furthermore, these skills were associated with higher publication outputs, and improved with mobility between institutions at postdoctoral level. This paper also describes how the findings from the baseline evaluation were used to develop a programme to address the lower ranking skills and evaluate the impact of the programme.
\end{abstract}

\section{Introduction}

In the United Kingdom (UK) in the 1990's, concerns were growing amongst the research funding bodies regarding $\mathrm{PhD}$ completion rates and the work skills $\mathrm{PhD}$ postgraduates could bring to the economy. Commissioned by the government, Sir Gareth Roberts, produced a report that reviewed the supply of science and engineering skills (Roberts 2002). It was reported that there had been unsatisfactory training in skills required for both academic and non-academic careers for contract research staff. Recommendations included the introduction of a minimum of 2 weeks per year transferable employability skills development. The outcome of the report was a new government funding scheme, known as "Roberts Funding" delivered by the Research Councils to allow Universities to implement the recommendations.

Since then a number of reviews (Leitch (2006) and Lambert (2003)) and policy documents (European Commission (2005) and Concordat (2008)) on skills and employment have been commissioned by the government to enhance the skills and employability of workers including fixed term contract researchers. These initiatives agreed on the requirement for higher quality training which meet the needs of employers.

Within the School of Medicine, at the University of Sheffield, this project was driven in 2006 by the clear need to deliver greater training and career support to a contract research staff population that had become de-motivated, had poor self-awareness, 
lacked career planning and structure and had limited involvement in the School and University. The vision was to create a training and career development programme designed by and tailored for the researchers on fixed term contracts (the majority of which are postdoctoral researchers) which also improved the career structure within the School and engaged the researchers. A postdoctoral researcher's society was set up in order to encourage dialogue between the researchers and the School management groups. It empowered them to speak out about their issues and become involved in improving the support that was needed. Additionally, a Committee was established with membership from the academic staff, post-doctoral researchers, the University of Sheffield Research and Innovation Services and the Medical School Research Team to respond to these issues by launching a career development programme and assessing its effectiveness.

Assessment of the baseline level of skills, experiences and achievements is therefore important to establish what skills should be improved and as a benchmark to relate back when measuring progress. Bromley et al, (2007) reported the successful use of a competency-based self assessment method to capture the baseline skills of research students. However to date, baseline studies of postdoctoral researchers, before a training programme has been established, has not been reported.

This study reports for the first time the baseline self perception of skill levels of postdoc researchers in our Faculty. The skills of those who are more successful academically, have been a postdoc for longer or have experience of working in other institution have been compared against the mean to identify skills that have benefitted them. These data has been used to design a new, specifically tailored training programme for the postdoctoral researchers in the School.

\section{Methodology}

\section{Design of the study}

A questionnaire (appendix 1) was designed to determine the experiences, opportunities and challenges of postdoctoral researchers in the areas of academic achievements, the research environment they currently worked in, previous experience, future career motivations and an analysis of their skills. The first sections on induction and previous experience enables collection of demographic data on the participants to compare various factors such as time as a postdoc and location of research career to further information gathered in the questionnaire.

It was vital to researcher development nationally that a shared understanding was reached regarding the skills that researchers required in order to progress and develop their skills. The UK Research Council produced the Joint Skills Statement (JSS) (RCUK 2001) which presents the skills a $\mathrm{PhD}$ postgraduate requires in the form of a list of competencies and this was adopted in the context of this research .

Not until recently in 2009, was there an equivalent national statement for research staff. Vitae (2009) developed an overarching competency framework termed the Researcher Development Framework which builds on the JSS in full, in order to address this need (Vitae 2009). The framework promotes professional development to 
researchers (from the start of a $\mathrm{PhD}$ through to Professor) by describing the knowledge, skills, behaviours and personal qualities a researcher should strive to develop. Without the Framework it was felt that although the JSS skill levels should have already been met by postdoctoral level researchers, this recognised standard would be the most suitable measure of skills and had previously been used by Bromley et al (2007) to develop a baseline needs analysis tool for $\mathrm{PhD}$ students. In the present study a five-point scale was used to score researchers perceptions of their skills, where 1 was deemed to be poorly skilled in that area and 5, excellent skills.

The survey also included questions on the research environment to identify possible links with how a researcher's opinions of the School might have an effect on their skills and productivity. Academic achievements to gauge researcher's success in publishing, grant funding and presenting their research findings also featured as did respondents future career plans to identify any differences in achievements or skills between the various categories. The questionnaire was also designed to report on the training and development needs of the researchers, in order to design a new training and development programme specifically tailored to the needs of the postdoctoral researchers.

The questionnaire was administered to all postdoctoral researchers $(n=150)$ in the School of Medicine at the University of Sheffield. The project obtained ethical approval by The University of Sheffield's research ethics committee. 46 of the 150 questionnaires were returned representing a $31 \%$ response rate.

\section{Data Analysis}

The mean score for each individual skill was calculated and ranked from highest to lowest. To determine if the skills perception score was significantly higher or lower than expected the mean for all scores was calculated (3.7) and each skill perception score was tested against this using a one-sample t-test.

A two-independent-sample t-test was used to examine differences between skills perception by researchers who did their $\mathrm{PhD}$ in Sheffield or at another institution and for those who had been a post-doc in Sheffield only or those who had undertaken a post-doc elsewhere. To analyse the effect of time spent as a post-doc, firstly the median time spent as a post-doc was calculated (5 yrs) and then a two-independentsample t-test was used to investigate differences between those who had been a postdoc for less than 5 years and those who had been a post-doc for 5 years or more.

To examine the relationship between skills perception and numbers of poster or papers that respondents had published the Kendall-Tau test for correlation was performed. Finally, to analyse the correlation between time as a post-doc and publications Spearman rank correlation was used as neither of these data follow normal distribution. All analysis was performed using SPSS 16.0. 


\section{Results}

Communication and awareness of the Research Environment in which successful research takes place are the weakest skills.

The distribution of scores from all ranked skills (1606) across the 46 respondents is shown in Figure 1. The mean for all scores was encouraging at 3.7 as this is just higher than the stated average skill rating of 3 from the population as stated as the middle score on the questionnaires 1-5 ranking options. Of significance $61 \%$ of the skills ranked were above average. However, these skills are associated with researchers at $\mathrm{PhD}$ level, with $39 \%$ of skills being average or below average. Such instances suggest that the latter group would benefit from further training.

Figure 1. Distribution of levels of the 36 skills reported by the population of postdoctoral researchers $(n=1606$, not including blanks). A score of 1 equates to "poorly skilled" and 5 "excellent skills".

There were eight competencies which researchers rated themselves significantly more skilled compared to the mean. These are ranked in Table 1 and include skills within the areas of 'Research skills and techniques', 'Personal effectiveness" and 'Teams/networking'. Most respondents $(n=39)$ rated themselves as having good or excellent research skills capable of recognising and validating problems, demonstrate original independent and critical skills and analysis and knowledge of recent advances in their field. Participants felt they understood research methods and able to apply them in the field. This finding is to be expected from a group of postdocs with several years' research experience. Whilst most felt confident in reviewing and evaluating research findings interestingly at least 15 respondents (out of 46) felt less confident in their capacity for critical thinking and originality.

Table 1. Summary of the 8 top rated self-assessed skills for the overall population.

\begin{tabular}{|c|c|l|r|c|c|c|}
\hline $\begin{array}{c}\text { Ran } \\
\mathbf{k}\end{array}$ & $\begin{array}{l}\text { JSS } \\
\text { Are } \\
\mathbf{a}\end{array}$ & JSS Description & $\begin{array}{c}\text { Mea } \\
\mathbf{n}\end{array}$ & $\begin{array}{c}\text { Std } \\
\mathbf{d e v}\end{array}$ & $\begin{array}{c}\text { SE } \\
\mathbf{M}\end{array}$ & $\begin{array}{c}\text { P } \\
\text { VALU } \\
\mathbf{E}\end{array}$ \\
\hline 1 & \multicolumn{1}{|l|}{ D } & $\begin{array}{l}\text { Show willingness/ability to learn and } \\
\text { acquire knowledge }\end{array}$ & 4.2 & 0.6 & 0.1 & $<0.001$ \\
\hline 2 & D & $\begin{array}{l}\text { Show initiative, work independently } \\
\text { and be self-reliant }\end{array}$ & 4.1 & 0.6 & 0.1 & $<0.001$ \\
\hline 3 & F & $\begin{array}{l}\text { Understand one's impact on others } \\
\text { when working in a team }\end{array}$ & 4.0 & 0.7 & 0.1 & 0.002 \\
\hline 4 & B & $\begin{array}{l}\text { Justify principles/techniques used in } \\
\text { your own research }\end{array}$ & 4.0 & 0.6 & 0.1 & $<0.001$ \\
\hline 5 & A & $\begin{array}{l}\text { Summarise, report and reflect on } \\
\text { progress }\end{array}$ & 4.0 & 0.6 & 0.1 & 0.001 \\
\hline
\end{tabular}




\begin{tabular}{|c|c|l|r|r|r|r|}
\hline 6 & D & $\begin{array}{l}\text { Show self-discipline, motivation and } \\
\text { thoroughness }\end{array}$ & 4.0 & 0.7 & 0.1 & 0.007 \\
\hline 7 & F & $\begin{array}{l}\text { Listen, give and receive feedback and } \\
\text { respond perceptively to others }\end{array}$ & 4.0 & 0.7 & 0.1 & 0.008 \\
\hline 8 & A & \begin{tabular}{l} 
Recognise and validate problems \\
\hline
\end{tabular} & 3.9 & 0.6 & 0.1 & 0.002 \\
\hline
\end{tabular}

Most participants saw themselves as flexible, open-minded and self-aware capable of identifying their own research training needs and motivated to do so drawing upon sources of support. Being able to communicate their research producing a coherent argument and articulate ideas was seen as important and skills and attributes that most respondents felt they had. However, several $(n=12)$ suggested they would value further training in teaching and mentoring others.

Despite suggesting the need for further education and training in relation to project management $(n=8)$, respondents perceived that they had excellent networking and teambuilding skills. This is possibly because they saw project management as a practical endeavour in terms of managing funds and meeting timelines as opposed to task allocation through people management.

In the top ranked skills, there is an absence of skills in the Categories of 'Research Management', 'Communication' and 'Career Management and therefore would be suitable areas to initially focus on when a training and development programme is designed.

The eight competencies that were ranked significantly lower than expected from the mean skill level are shown in Table 2. All of the communication skills scored in the bottom half of the rankings with the promoting the public understanding of science ranked lowest overall. This is a skill that is often unused by many Principle Investigators (PI) and therefore understandable that many junior researchers have not taken up the opportunity to practise this skill. In recent years, a greater number of funding bodies have been asking to see evidence of public engagement in their applications. This commitment to improving public engagement is highlighted in the RCUK's recent 'Expectations for Societal and Economic Impact' statement (RCUK 2009). In return for those who receive funding, RCUK expect that researchers will 'engage actively with the public at both the local and national levels about their research and its broader implications'. In these terms this is a key area for inclusion in education and training programmes.

Table 2. Summary of the 8 lowest rated self-assessed skills for the overall population.

\begin{tabular}{|c|l|l|r|r|r|r|}
\hline Rank & $\begin{array}{l}\text { JSS } \\
\text { Area }\end{array}$ & JSS Description & Mean & $\begin{array}{l}\text { Std } \\
\text { dev }\end{array}$ & SEM & $\begin{array}{r}\text { P } \\
\text { VALUE }\end{array}$ \\
\hline 1 & E & $\begin{array}{l}\text { Contribute to promoting public } \\
\text { understandings of research }\end{array}$ & $\mathbf{2 . 7}$ & 1.0 & 0.1 & $<0.001$ \\
\hline 2 & $\mathrm{~B}$ & $\begin{array}{l}\text { Understanding the process of } \\
\text { academic and commercial } \\
\text { exploitation of research results }\end{array}$ & $\mathbf{3 . 0}$ & 1.0 & 0.1 & $<0.001$ \\
\hline
\end{tabular}




\begin{tabular}{|c|c|c|c|c|c|c|}
\hline 3 & $\mathrm{G}$ & $\begin{array}{l}\text { Show an insight into the transferable } \\
\text { nature of research skills to other } \\
\text { work environments and range of } \\
\text { careers e.g. communication, } \\
\text { supervisory and analytical skills etc }\end{array}$ & 3.2 & 0.9 & 0.1 & 0.002 \\
\hline 4 & B & $\begin{array}{l}\text { Understand the process of funding } \\
\text { and evaluating research }\end{array}$ & 3.2 & 0.8 & 0.1 & 0.002 \\
\hline 5 & $\mathrm{G}$ & $\begin{array}{l}\text { Present one's skills, personal } \\
\text { attributes and experiences through } \\
\text { effective CVs, applications and } \\
\text { interviews }\end{array}$ & 3.2 & 0.9 & 0.1 & 0.003 \\
\hline 6 & $\mathrm{E}$ & $\begin{array}{l}\text { Defend research outcomes at } \\
\text { seminars }\end{array}$ & 3.3 & 0.8 & 0.1 & 0.001 \\
\hline 7 & B & $\begin{array}{l}\text { Show an awareness of issues } \\
\text { relating to ; rights of other } \\
\text { researchers, of research subjects and } \\
\text { other affected by research } \\
\text { (confidentiality, ethics, ownership } \\
\text { of data etc) }\end{array}$ & 3.3 & 0.9 & 0.1 & 0.007 \\
\hline 8 & $\mathrm{G}$ & $\begin{array}{l}\text { Take ownership for one's career } \\
\text { progression, setting realistic goals } \\
\text { and improving employability }\end{array}$ & 3.4 & 0.9 & 0.1 & 0.051 \\
\hline
\end{tabular}

Under the category of Research Environment and Research Management, respondents felt that their powers of project management and grant capture were left wanting, several lacking confidence. Specifically, several respondents worryingly indicated that they did not understand the process of research grant capture and funding or the process of academic and commercial exploitation of results. Knowledge of the ethical dimensions of research was also perceived to be limited, respondents suggesting the need for further training.

Interestingly the skills associated with the area 'Research environment' were present in both the highest and lowest ranking skills. It is clear that this category of the JSS contains a variety of skills. Skills, which were more obviously related to the post-doc personal research (e.g. justify research techniques) scored high, however, skills which were related to the ability to see research in a wider context scored low.

Showing an insight into the transferable nature of research skills was considered an important attribute and further training was requested. Integral to this process was; the capacity to supervise; produce a professional Curriculum Vitae; submit effective high calibre job applications; and, present oneself confidently at interview. It was therefore clear that although researchers were committed to career development, they felt they were lacking in these skills. Indeed career management skills featured in the lowest eleven ranked skills.

Respondents $(n=40)$ further indicated that they planned to continue to work in academia in an institute of higher education, and 29 of these saw themselves remaining at their current institution. This reflects the national trend seen in surveys such as the CROS (2009) where the majority of postdoctoral researchers wish to 
continue with an academic career. Several respondents saw themselves working towards a senior academic position including professorial, a permanent lectureship, senior research scientist and scientific officer in a laboratory management role. However, there was much mention of how it was felt that their planned career trajectory hinged on a willingness to continue in a succession of non permanent/fixed term contract positions. Others planned to work in the science industry $(n=5)$, non science sector $(n=1)$, retrain for another career $(n=2)$, become self-employed $(n=3)$ move abroad $(n=4)$ or were unsure. One respondent was especially disenchanted with academic life and asserted they would do 'almost anything except staying in academia'.

Table 3 shows the comparison between researcher's skills and whether they wished to continue with an academic career. Those wishing to stay in academia had significantly higher skills at understanding the context in which research takes place and showed a trend towards having more self-discipline, motivation and thoroughness. Surprisingly those researchers who wished to stay in academia perceived themselves to have significantly lower project management skills than those who did not wish to stay.

Whilst more than $50 \%$ of researchers $(n=29)$ planned to remain in their current institution over half of these 29 respondents felt this would not be realised due to a range of obstacles listed in Table 4. Some respondents felt disillusioned by their lack of future directions in their career; 'once you have a PhD...you seem to go into a career cul-de-sac and its very hard to change direction'. Essentially respondents felt that their doctorate was seen as an end in itself with limited if any attention to post doctoral career and career development. This issue was summarised well in the following respondent's quote: "I don't know where to go from here. All I can see is years and years of short term contracts as an undervalued post doc". 
Table 3 Comparison of skill levels for those who wish to continue a career in academia, compared to those who do not wish to continue in academia

\begin{tabular}{|l|l|l|l|}
\hline JSS Description & $\begin{array}{l}\text { Yes } \\
\mathbf{( n = 2 7 )}\end{array}$ & $\begin{array}{l}\text { No } \\
(\mathbf{n = 1 1})\end{array}$ & $\begin{array}{l}\text { P } \\
\text { value }\end{array}$ \\
\hline $\begin{array}{l}\text { Show broad understanding of the context } \\
\text { (nationally and internationally) in which research } \\
\text { takes place }\end{array}$ & 3.80 .1 & 3.30 .2 & 0.035 \\
$\begin{array}{l}\text { Project manage by setting goals, milestones and } \\
\text { prioritise }\end{array}$ & 3.80 .1 & 4.20 .1 & 0.047 \\
$\begin{array}{l}\text { Show self-discipline, motivation and thoroughness } \\
\text { Show }\end{array}$ & 4.10 .1 & 3.70 .1 & 0.080 \\
\hline
\end{tabular}

Table 4: Quoted obstacles to career progression

\begin{tabular}{|l|l|}
\hline Institutional & Insufficient external fellowships \\
\hline \multirow{2}{*}{ Insufficient lectureships } \\
\hline & $\begin{array}{l}\text { Salary has become too expensive for many post } \\
\text { doc positions }\end{array}$ \\
\hline Short term contracts only \\
\hline Professional & $\begin{array}{l}\text { Depends on whether the company funding the } \\
\text { research stays afloat }\end{array}$ \\
\hline & $\begin{array}{l}\text { Publication record not good enough } \\
\text { No academic career for researchers per se }\end{array}$ \\
\hline & $\begin{array}{l}\text { Little support for continuous research only } \\
\text { lectureships and research }\end{array}$ \\
\hline & CV not good enough to get a lectureship \\
\hline
\end{tabular}

\section{The skill levels of researchers plateau with time and increase with mobility}

Participants were asked how long they had been a postdoc. The median length of time spent as a post-doc was 5 years. Surprisingly, there was no significant difference in the majority (30) of skills between the group with 5 or more years post-doc experience and those under 5 years experience. This suggests that the skill levels of researchers by 5 years experience do not significantly improve with time.

Only 5 of the skills that saw an increase with time as a postdoc were statistically significant and all of these were from the 'Research Environment' skills area, which is understandable as there are perceived to be more related to the day to day activities of a researcher. A trend of 6 skills were perceived to be worse in researchers with 5 or more years experience with the worst being 'show self discipline, motivation and thoroughness'. It is likely that those respondents who have been postdocs for many years are becoming disillusioned with their career prospects and losing motivation for 
their work.

Researchers were asked where they had carried out their $\mathrm{PhD}$ and previous postdoctoral experience. Most respondents obtained their $\mathrm{PhD}$ at Sheffield ( $\mathrm{n}=25$ / 54\%) with the remainder awarded at other UK institutions, whilst two candidates had studied overseas and were awarded their $\mathrm{PhD}$ in Germany and the other in Russia. There was no significant difference in skills perceptions between post-docs who had been awarded their PhD in Sheffield compared to those who had been awarded their $\mathrm{PhD}$ at an alternative institution. In contrast, researchers who had held a post-doc position somewhere other than Sheffield, irrespective of where they did their $\mathrm{PhD}$, score themselves higher for every single skill assessed except the following which were scored equally:

- - Appreciate standards of good research practice in the School/University

- $\quad$ Show initiative, work independently and be self-reliant

- - Contribute to promoting the public understanding of research

Overall, the trend revealed that those researchers who only have experience of one institution perceive they are much less skilled as a researcher and therefore are on average much less employable. It is clear that researchers who experience postdoctoral contracts in different locations have a greater confidence in their skills and are much more aware of the research environment and the process of research.

\section{Researchers who are more outwardly focussed have a better publication record.}

To determine the skills associated with a successful researcher respondents were asked about their publication and presentation records, as an indicator of their performance. They were asked to report on the number of first, middle and last author papers and the number of oral and poster presentations they had given. There was a significant correlation between skills related to a broader understanding of science and issues related to research and the number of papers published. The results are shown in Table 5. Interestingly, the number of first author papers correlated with understanding the process of acquisition of funding and perceived ownership of career progression.

It is arguable that the researchers with a lower publication had better quality publication and so the number of papers published would not be a measure of productivity. To ensure that this was not the case the named respondents' $(n=21)$ publication records were assessed using ISI Web of Science ${ }^{\mathrm{SM}}$ to identify the average citation per paper for each individual. The results of the average citation against the number of publications are plotted in Figure 2 and show a weak positive correlation $\left(\mathrm{R}^{2}=0.27\right)$ between paper numbers and citation rate/paper, suggesting that the lower number of papers of researchers is not due to better quality. It is of interest that those skills that were found to correlate significantly with higher publication numbers were also those which were found significantly below average in the ranking of perceived skills, reinforcing the importance of targeting those skills in the design of the training programme. 
Table 5 Skills that show a positive correlation to the numbers of publications and presentations (values in bold highlight those that are significant)

\begin{tabular}{|c|c|c|c|c|c|c|}
\hline & $\begin{array}{c}\text { First } \\
\text { author } \\
\text { papers }\end{array}$ & $\begin{array}{c}\text { Total } \\
\text { papers }\end{array}$ & Posters & & & \\
\hline $\begin{array}{l}\text { JSS } \\
\text { Descripti } \\
\text { on }\end{array}$ & $\begin{array}{c}\text { Correlati } \\
\text { on } \\
\text { Coefficien } \\
t\end{array}$ & P Value & $\begin{array}{c}\text { Correlatio } \\
\mathbf{n} \\
\text { Coefficien } \\
\mathbf{t}\end{array}$ & P Value & $\begin{array}{c}\text { Correlatio } \\
n \\
\text { Coefficien } \\
t\end{array}$ & P Value \\
\hline $\begin{array}{l}\text { Show } \\
\text { broad } \\
\text { understan } \\
\text { ding of } \\
\text { the } \\
\text { context } \\
\text { (nationall } \\
\text { y and } \\
\text { internatio } \\
\text { nally) in } \\
\text { which } \\
\text { research } \\
\text { takes } \\
\text { place }\end{array}$ & 0.230 & 0.067 & 0.318 & 0.009 & 0.187 & 0.129 \\
\hline $\begin{array}{l}\text { Show an } \\
\text { awarenes } \\
\text { s of } \\
\text { issues } \\
\text { relating } \\
\text { to ; rights } \\
\text { of other } \\
\text { researche } \\
\text { rs, of } \\
\text { research } \\
\text { subjects } \\
\text { and other } \\
\text { affected } \\
\text { by } \\
\text { research } \\
\text { (confiden } \\
\text { tiality, } \\
\text { ethics, } \\
\text { ownershi } \\
\text { p of data } \\
\text { etc) }\end{array}$ & 0.320 & 0.010 & 0.270 & 0.023 & 0.326 & 0.007 \\
\hline $\begin{array}{l}\text { Understa } \\
\text { nd the } \\
\text { process } \\
\text { of } \\
\text { funding }\end{array}$ & 0.212 & 0.087 & 0.147 & 0.221 & 0.389 & 0.001 \\
\hline
\end{tabular}




\begin{tabular}{|c|c|c|c|c|c|c|}
\hline $\begin{array}{l}\text { and } \\
\text { evaluatin } \\
\mathrm{g} \\
\text { research }\end{array}$ & & & & & & \\
\hline $\begin{array}{l}\text { Justify } \\
\text { principles } \\
\text { /techniqu } \\
\text { es used in } \\
\text { your own } \\
\text { research }\end{array}$ & 0.192 & 0.132 & 0.141 & 0.256 & 0.257 & 0.039 \\
\hline $\begin{array}{l}\text { Defend } \\
\text { research } \\
\text { outcomes } \\
\text { at } \\
\text { seminars }\end{array}$ & 0.323 & 0.010 & 0.279 & 0.023 & 0.198 & 0.108 \\
\hline $\begin{array}{l}\text { Take } \\
\text { ownershi } \\
\text { p for } \\
\text { one's } \\
\text { career } \\
\text { progressi } \\
\text { on, } \\
\text { setting } \\
\text { realistic } \\
\text { goals and } \\
\text { improvin } \\
\text { g } \\
\text { employab } \\
\text { ility }\end{array}$ & 0.305 & 0.014 & 0.087 & 0.468 & 0.087 & 0.473 \\
\hline
\end{tabular}


Figure 2 Correlation between the number of papers a researcher has and their average citation per paper $(n=21)$.

\section{Conclusions for the development of a tailored training programme}

The questionnaire provided a useful data collection tool for generating a comprehensive baseline analysis on assessment of skills, development needs, demographic details and achievement. To set a reference for future impact evaluation of the programme, it is vital to identify the training and development needs of the researcher and the skills required to be successful.

The questionnaire highlighted a number of skills which fell below average and needed to be addressed. These were related to the areas of career development communication and awareness of research environment. It was interesting to discover that those skills were the ones associated with higher publication rates and were improved by career mobility between institutions, suggesting that those skills are key to the development of researchers and their employability. A general lack of support for training and career development together with limited ability of supervisors to provide sound career advice was in agreement with the findings of Åkerlind (2005 and 2009).

The questionnaire had several limitations, including the lack of demographic data on sex and age of respondents and the ability to misinterpret one question regarding fellowship funding. However, the main limitation to the questionnaire was that it can only measure perceived and not actual skill levels of the researchers. Recommendations to overcome this limitation would be assessment of skill levels, although this would involve a benchmarking process for each skill assessed. Alternatively the same questionnaire could be posed to the researcher's line manager in order to determine the level of discrepancy.

Based on the findings from the baseline questionnaire a programme called "Think Ahead" (Figure 3) was launched aimed at addressing the key findings from this research including; skills training (particularly in the areas of communication and research environment), encouraging and supporting career development and the career trajectory of researchers, improving the timing researchers respond to support to reduce numbers of contract cycles and aiding researcher mobility. Table 6 highlights how some of the programme features respond to the researchers recommendations. 
Figure 3. 'Think Ahead' programme for post-doctoral researchers during a fixed term contract in the Medical School (SRDS $=$ Staff Review and Development Scheme) 
Table 6 Summary of development decisions related to the researcher's recommendations and needs analysis assessment

\begin{tabular}{|l|l|}
\hline $\begin{array}{c}\text { Researcher recommendation/ } \\
\text { Skill lacking }\end{array}$ & $\begin{array}{l}\text { Action taken to develop "Think Ahead" } \\
\begin{array}{l}\text { Communication Skills were all in } \\
\text { the bottom 17 of the skills } \\
\text { ranking }\end{array}\end{array} \begin{array}{l}\text { Development of workshops to include, } \\
\text { "presentation skills", "public communication } \\
\text { and outreach opportunities", "writing up your } \\
\text { research for publication" and "teaching and } \\
\text { tutoring workshop. Additional activities to } \\
\text { practise these skills include PhD mentoring, } \\
\text { teaching opportunities and organised outreach } \\
\text { activities with the public }\end{array}$ \\
\hline $\begin{array}{l}\text { Research Environment Skills } \\
\text { were lacking in the area of } \\
\text { commercial exploitation, funding } \\
\text { and evaluating researcher and } \\
\text { awareness of issues. }\end{array}$ & $\begin{array}{l}\text { Development of workshops to include, } \\
\text { "Writing a successful grant application", } \\
\text { "Ethics and Governance" and a scheme for } \\
\text { commercial awareness which includes a "An } \\
\text { introduction to commercial skills for life } \\
\text { scientists" and mentoring for groups through } \\
\text { the BioscienceYes competition. }\end{array}$ \\
\hline $\begin{array}{l}\text { Project management for those } \\
\text { wishing to stay in academia }\end{array}$ & $\begin{array}{l}\text { Development of SURE (Sheffield } \\
\text { Undergraduate Research Experience) that } \\
\text { enables Postdocs to be sole supervisors of } \\
\text { undergraduates carrying out research for 6 } \\
\text { weeks in the summer. This allows them to } \\
\text { experience grant writing, project and budget } \\
\text { management recruitment, supervision and } \\
\text { also gives the opportunity to generate } \\
\text { independent data that can be used in future } \\
\text { external grant applications. }\end{array}$ \\
\hline
\end{tabular}

In order to address the training and development needs identified in this study, a CPD programme was designed and developed. It was also deemed essential that the researchers themselves should be involved in the design and development of each course/event on the programme in order to ensure everything delivered meets the needs of the target audience. Cryer (1998) described the importance of linking skills training workshops to research skills development ideally embedded within the culture of the School in order to 'make the skills part of the researchers everyday thinking'. It was therefore vitally important that in order to create a high-quality training programme researchers engage with, their recommendations must be taken into consideration during development. Programme development would also need to centre on workshops that are linked with "working based learning opportunities" to embed these skills within the working environment of the researchers. Examples of these types of activities include; involvement in teaching and grant writing competitions.

Key issues in designing such a successful training programme to improve the skills of researchers include; (a) does it meet the stakeholder's needs, and; (b) is an understanding of which skills are required by the employers and are key to 
productivity and which of those skills are lacking in the workforce. Moreover a robust assessment of the programme is required to verify its effectiveness and refinement. In addition there have also been questions about how the effectiveness of researcher training programmes could be assessed and monitored (Cameron et al, 2006).

Training workshops on the programme are designed to cover many transferable skills deemed as lacking from the data reported in this research. The programme however, is not solely a series of standalone workshops but sessions that lead into additional working-based learning opportunities and outcomes that can be monitored in order to strengthen the learning by putting the taught theory into practise. It is important to identify what the key performance indicators of programme are, in order to measure the impact the programme is having. It is therefore anticipated that this programme will produce the following measureable outcomes which should not only enhance the employability of the researchers but also inherently benefit the School:

- - Increased numbers of publications from post-doctoral researchers

- $\quad$ Increased numbers of fellowships and grants obtained with the input of the researchers

- - Decreased numbers of researchers moving from contract to contract

- $\quad$ Increased number of researchers holding leadership positions outside the University and acting as ambassadors due to increased employability

The establishment of baseline data allows research to be carried out into the impact that specific training has on postdoctoral researchers and how that affects their perceived skills. For this reason, an evaluation model was designed alongside the programme from the beginning in order to be able to assess the impact of the development on the researchers in the future. Impact evaluation research regarding researcher development has started to emerge since we developed the model based on the study Alpay and Walsh (2008) have recorded the impact that attending a 3 day training course has on $\mathrm{PhD}$ student's skills. A skills perception inventory (SKIPI) was used before and after the course to evaluate skills development. In contrast, the CROS (Careers in Research Online Survey, 2009) conducted by higher education institutions, is designed to gather anonymous views of research staff regarding their experiences, employment, career aspirations and development.

The evaluation model designed for the "Think ahead" programme is outlined below and since the development of our model, the Rugby Team Impact Framework (RTIF) (described in Bromley (2009)) was released which can now be used as a common language across the sector to gauge the level at which a particular evaluation activity can be placed. In response to this, our model has been mapped to the Framework and will be compared back to the baseline research as reported in this study.

The programme will be evaluated as a whole, covering levels 0-4 of the RTIF. After 2 years of the programme we will repeat the baseline questionnaire, surveying all postdoctoral researchers across the School and compare the results against the initial baseline review in order to report changes that have been made both to the School as a whole and to selected individuals. There will also be an element of focus groups and interviews/discussions. Change will also be monitored using comparisons between numbers of external grants and fellowships applied for and awarded as sole or coapplicant, publication records, awards, training engagement levels and CPD activity uptake (e.g. numbers of postdocs now carrying out public communication activities). 
Case studies on an individual's exposure to and impact from the training programme will also be reported on.

Activities such as workshops, working-based learning opportunities, career days and the career mentoring scheme within the programme are also evaluated on an individual basis. The evaluation process covers levels 0 to 4 and includes; needs analysis, expectation identification and outcome determination in their design, on the day reactionnaires, 6 monthly questionnaires to assess learning and behaviour changes and long-term outcome monitoring. The data gathered at all levels is compiled and used to make modifications to the design and delivery of every session in order to further meet the needs of the target audience.

In conclusion this study successfully demonstrates the use of a baseline investigation of contract research staff in order to develop a specifically tailored training and development programme, based on the recommendations of the respondents and the skills rankings. Results revealed that perceived skill levels are affected by mobility and time spent as a researcher. The skills linked to publication productivity were also highlighted. Further evaluation of subsequent development opportunities for contract research staff in the School will allow impact to be measured against the baseline data.

\section{Acknowledgements}

The authors would like to acknowledge the financial support provided by the Roberts' fund, University of Sheffield and RCUK. Special thanks is given to Dr Stephen Walters (ScHARR, University of Sheffield) for his statistical support. Additionally the authors thank all the participants who took part in the study.

\section{References}

Åkerlind, G (2005) Postdoctoral researchers: roles, functions and career prospects. Higher Education Research and Development, 24, 1, 21-40

Åkerlind, G (2009) Postdoctoral researcher positions as preparation for an academic career. The International Journal for Researcher Development 1 84-96

Bromley A. P., Boran, J. R. and Myddelton, W. A. (2007) Investigation the baseline skills of research students using a competency based self-assessment method. Active Learning Higher Education 8, 2 117-137

Bromley, T. (2009) Evaluation Training and Development Programmes for Postgraduate and Newer Researchers Issues in Postgraduate Education: Management, Teaching and Supervision. Society for Research into Higher Education

Cameron, G., Clarke, H., Dalglish, P., Denicolo, D., Evans, J., Ewing, S., Felton et al (The Rugby Team) (2006). Evaluation of skills development of early career researchers - a strategy paper from the Rugby Team. Paper presented at the UK GRAD Programme Roberts Policy Forum, January.

Concordat (2005) UK Concordat to Support the Career Development of Researchers. 
$\underline{\text { www.researchconcordat.ac.uk }}$

CROS (2009) Careers in Research Online Survey: analysis of aggregated UK results. Careers Research and Advisory Centre (CRAC) Limited.

Cryer, P. (1998) Transferable skills, marketability and lifelong learning: The particular case of postgraduate research students, Studies in Higher Education, 23, 207-216

European Commission (2005) European Charter for Researchers and Code of Conduct for their recruitment.

ec.europa.eu/eracareers/pdf/am509774CEE_EN_E4.pdf

Mandelson, P. (2009) Higher Ambitions Business Secretary's speech to the CBI HE Conference

nds.coi.gov.uk/clientmicrosite/content/Detail.aspx?ReleaseID $=407694 \&$ NewsAreaID $=2 \&$ ClientID $=431$

Lambert, R. (2003) Lambert Review of Business-University Collaboration www.lambertreview.org.uk

Leitch, S. (2006) Prosperity for all in the global economy - world class skills Leitch Review of Skills Final Report.

http://webarchive.nationalarchives.gov.uk/+/http://www.hm-

treasury.gov.uk/d/leitch_finalreport051206.pdf

RCUK (2001) 'Joint Statement of the Research Councils'. AHRB's Skills Training Requirements for Research Students, Research Councils.

www.vitae.ac.uk/CMS/files/upload/RCUK-Joint-Skills-Statement-2001.pdf

RCUK (2009) RCUK Expectations for Societal and Economic Impact http://www.rcuk.ac.uk/cmsweb/downloads/rcuk/innovation/expectationssei.pdf

Roberts, S. G (2002) 'SET for success- The supply of people with Science, Technology, Engineering and Mathematics Skills' Report of Sir Gareth Roberts Review, Higher Education Funding Councils of England, Scotland and Wales: www.hm-treasury.gov.uk/d/robertsreview introch1.pdf

Vitae (2009) Researcher Development Framework. vitae.ac.uk/policypractice/165001/Researcher-development-framework-consultation.html 


\section{Appendix 1:}

\section{Baseline Questionnaire}

The Postdoc Society would like to assess the training needs of the Postdocs within the School in order to further develop the new Postdoctoral Research Professional Development Program. We would also like to find out about your experience of working within the School and the opportunities you have been given.

Please could you take about 10 minutes to fill in this questionnaire? This will allow us to individually tailor the program to everyone's needs and we can effectively evaluate the success of the program over the next 2 years by using this as a baseline for comparison.

Completed questionnaires will not be seen by academic members of staff. Dr. Lucy Lee (Postdoctoral Research Training and Development Advisor) will collate the information provided and create an anonymous summary of the data. All information will be treated in the strictest confidence. Only the summary will be used to make necessary changes to the School and tailor the workshops to individual needs. More information about the Development Program can be found at the Postdoc Website:

http://www.shef.ac.uk/medicine/staff-info/postdoc

\section{1) Induction:}

Did you receive any of the following in an induction when you joined the School?

Please tick all that apply:

Welcome to the University (Central Talk)

Induction for new staff (Web based course)

Were you told about the Learning Management System (LMS)

Information about School and University structure

Information about courses offered

Medical School Induction Pack

\section{2) Previous Experience:}

2.1) Where did you carry out your $\mathrm{PhD}$ ?

2.2) If you have previously worked as a Postdoc elsewhere, where did you work?

2.2) What made you choose the University of Sheffield, School of Medicine and Biomedical Sciences?

2.3) How many years Postdoc experience do you have in total (i.e. Sheffield and elsewhere)?

2.4) How many years have you worked as a Postdoc in Sheffield?

2.5) What was the start date of your first Postdoc in Sheffield?

\section{3) Skills Analysis:}

This section is based on the Joint Skills Statement of the UK Research Councils' skills training requirements for research students. Please indicate (by ticking in the appropriate box) how competent you feel you are at each of the following skills on a 5 point sliding scale from poor to 
excellent. Each question begins: "Researchers should be able to...". Please tick the final box if you would like to receive training in a particular area.

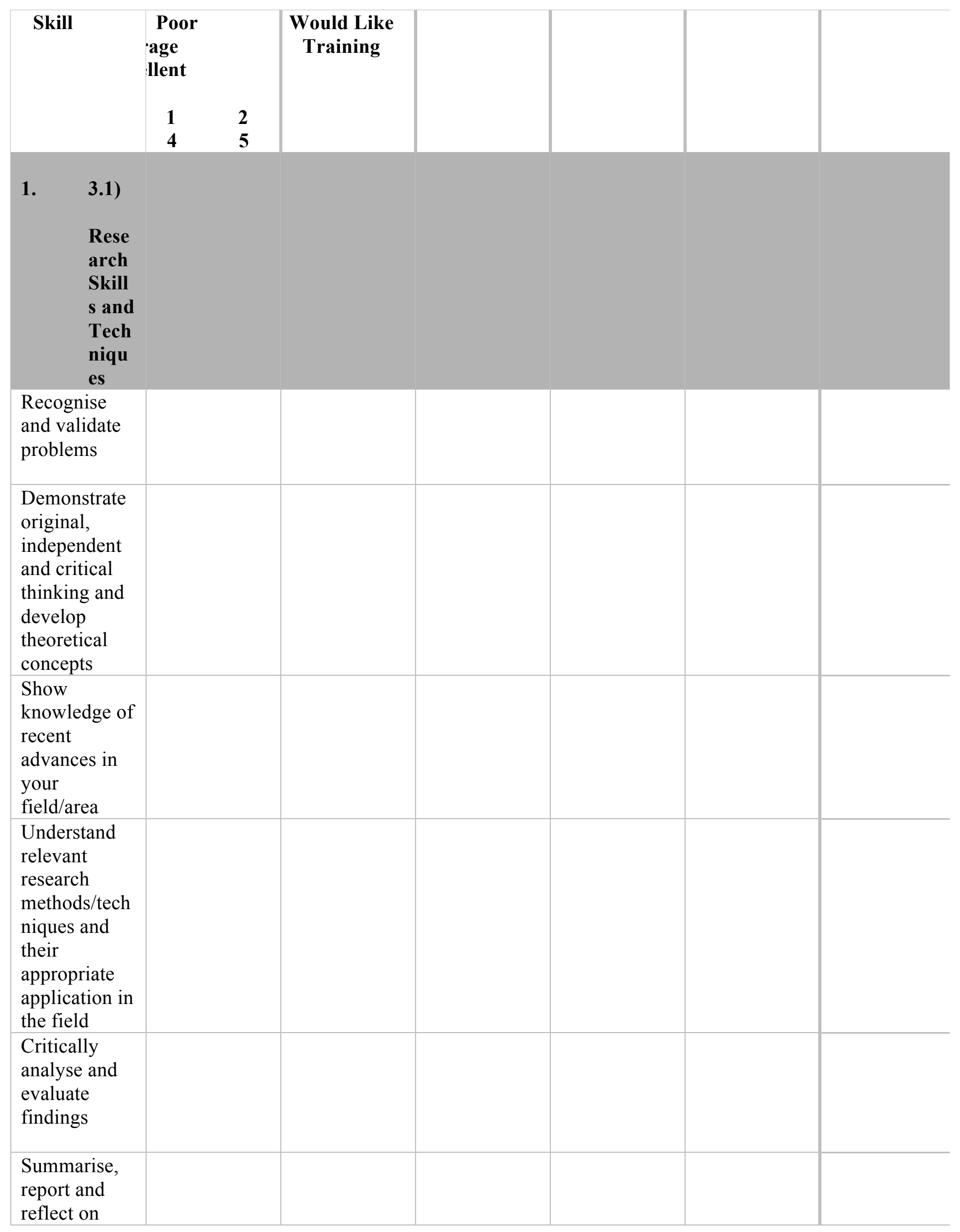


progress

1. 3.2)

Rese

arch

Envi

ron

ment

Show broad

understandin

$\mathrm{g}$ of the

context

(nationally

and

internationall

y) in which

research

takes place

Show an

awareness of

issues

relating to;

rights of

other

researchers,

of research

subjects and

other affected

by the

research

(confidentiali

ty, ethics,

ownership of

data etc)

Appreciate

standards of

good

research

practice in

the

School/Unive

rsity

Understand

health/safety

issues

Understand

process of

funding and

evaluating

research

Justify

principles/tec 


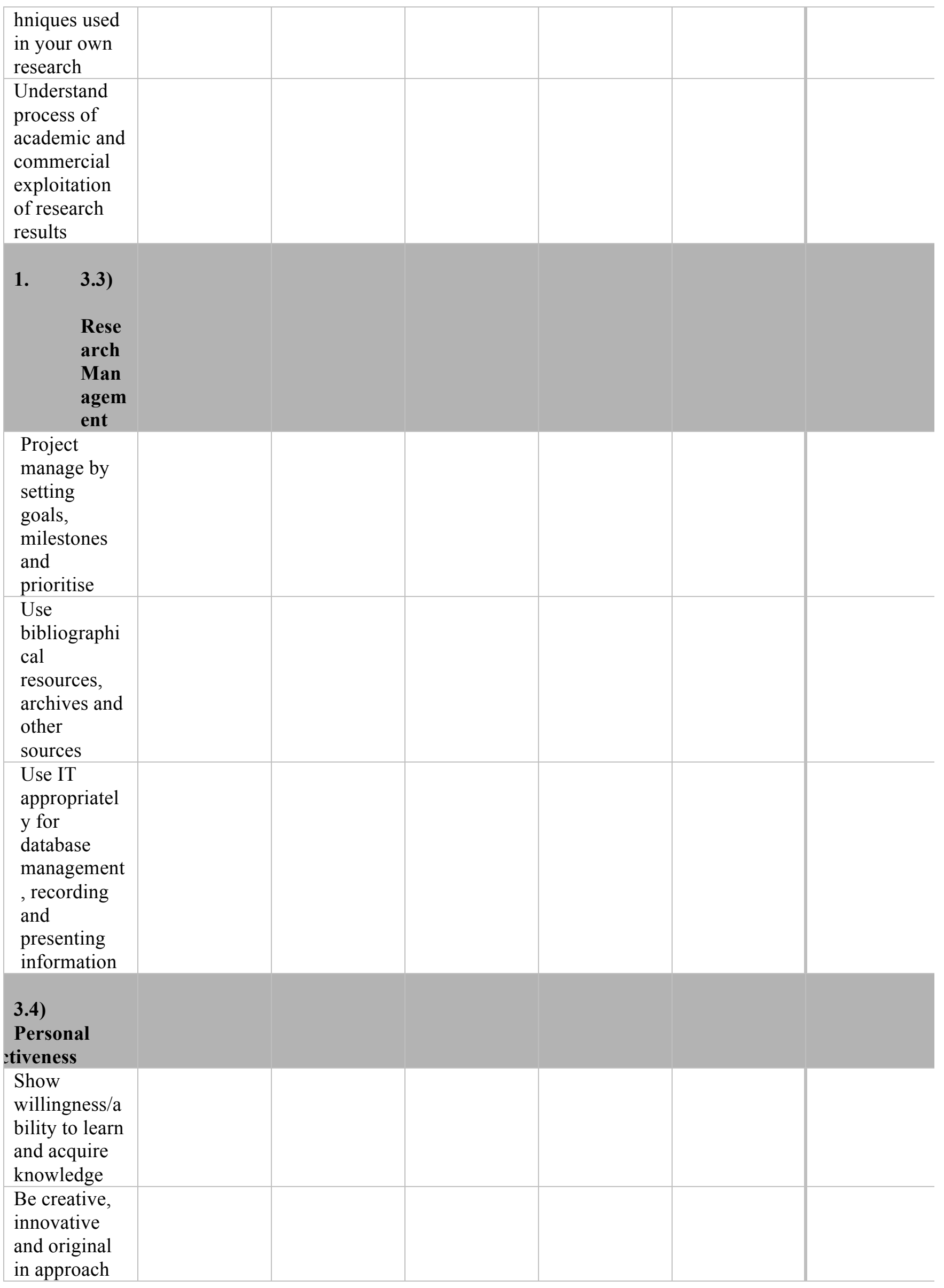




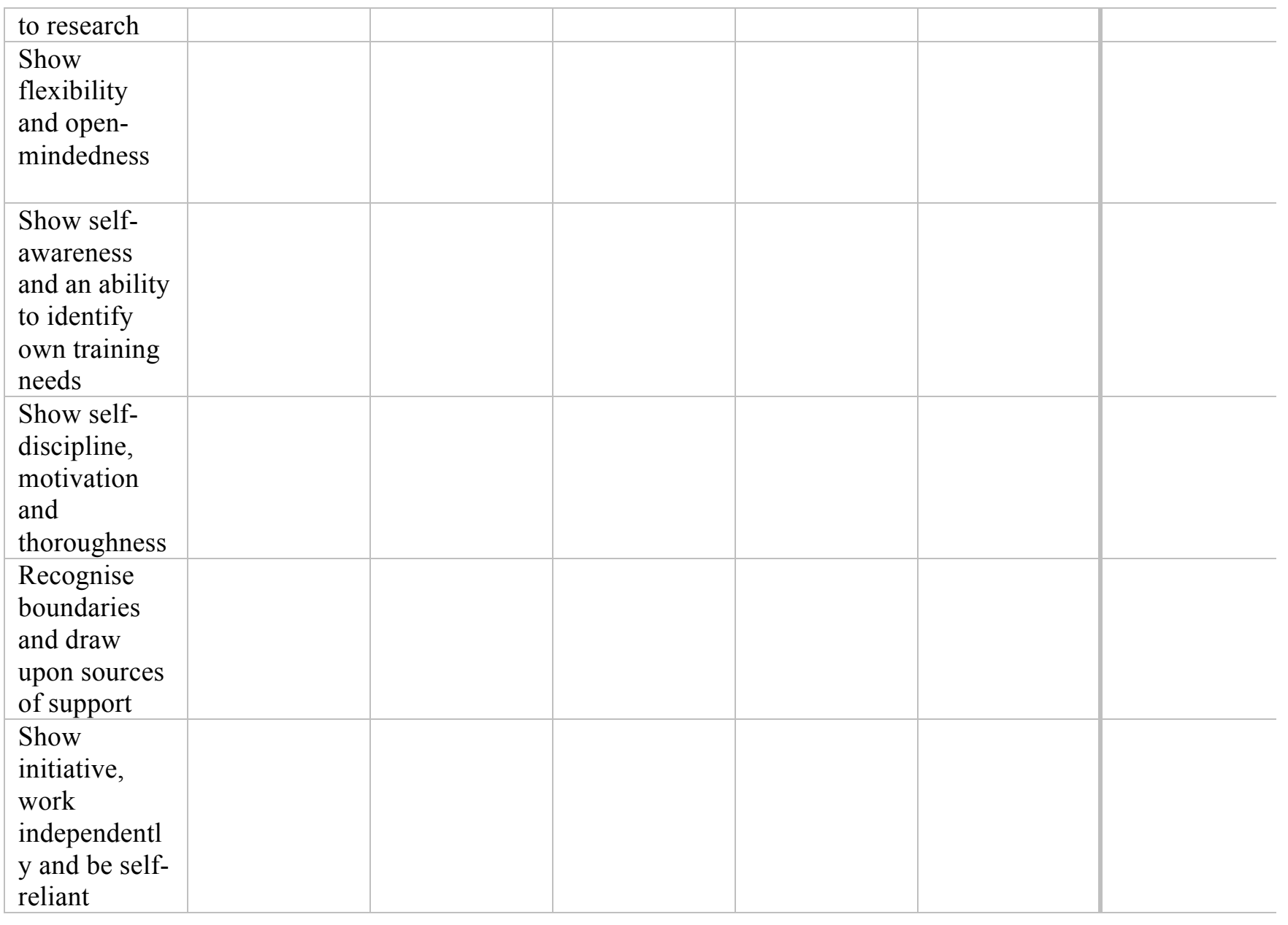

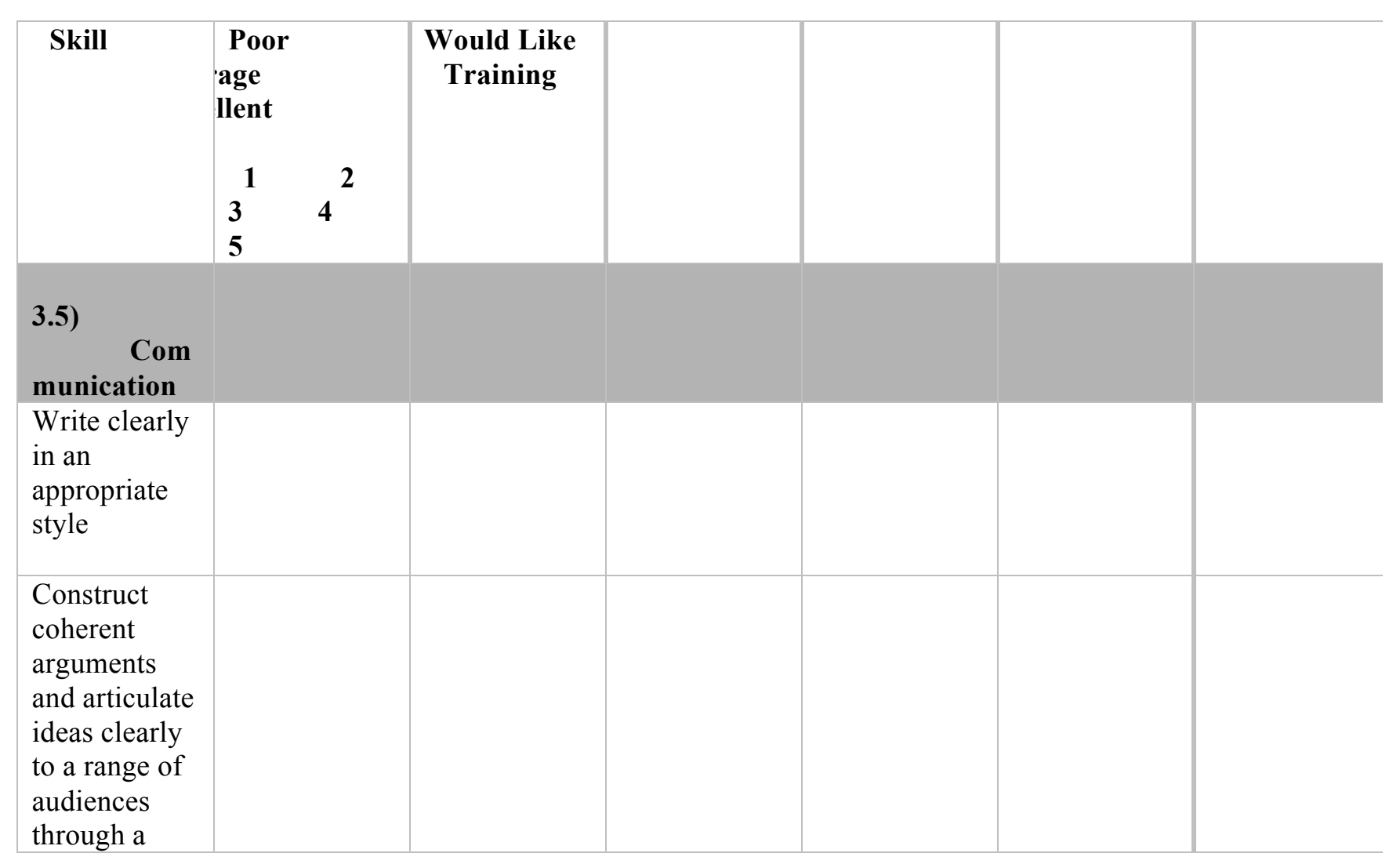




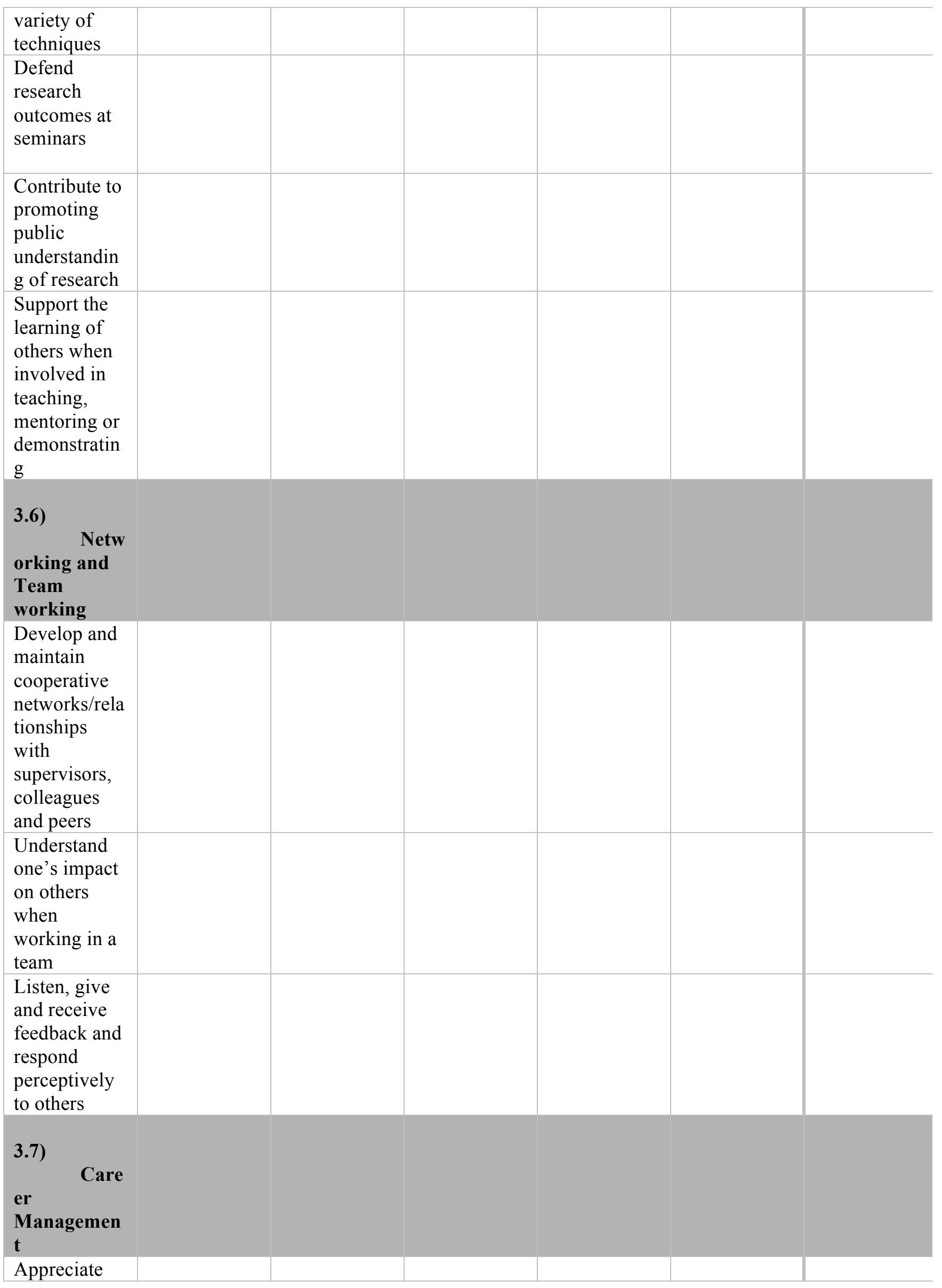




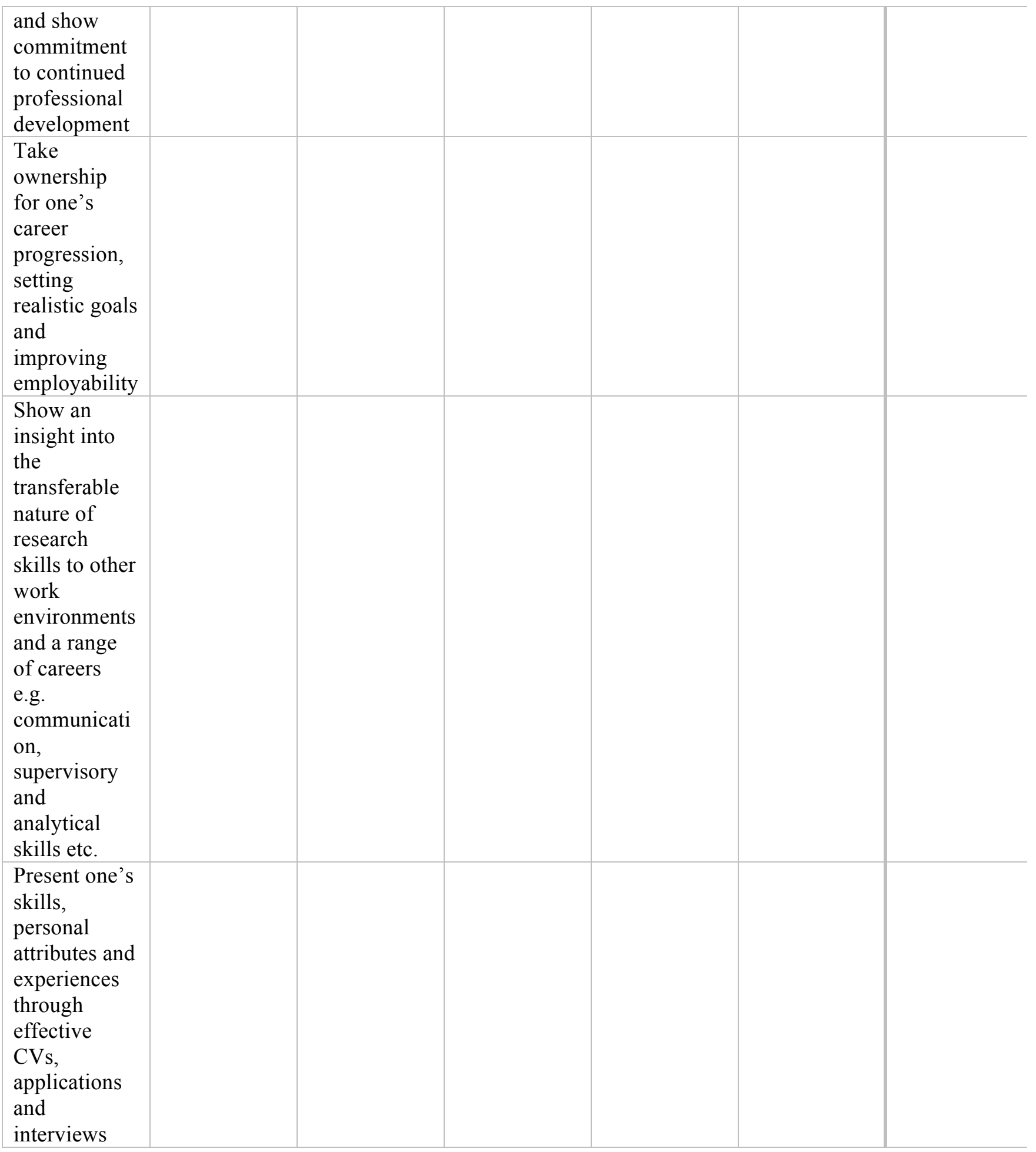

4) Medical School Environment:

4.1) Would you recommend working in the Medical School to someone else?

Yes No

If no, please state why:

4.2) Do you feel part of a community or team?

Yes No

If no, please state why:

4.3) Do you have the support that you need for: 

a) Your research?
Yes
No
Not sure
b) Training needs?
Yes
No
Not sure
c) Career development?
Yes
No
Not sure

\section{4.4) How does the Medical School compare to previous places you have} worked/studied?

Better Same Worse N/A

Other

Please explain you response:

\section{5) Scientific Career:}

1. 5.1) Publishing in peer-reviewed journals:

How many $1^{\text {st }}$ author papers do you have?

How many last author papers do you have?

How many middle author papers do you have? a) in press

b) in preparation

a) in press

b) in preparation

a) in press

b) in preparation

What barriers have you come across when trying to publish?

\section{2) Have you ever presented your research at a scientific conference?}

Yes

No

If yes:

How many oral communications have you presented?

How many of the above talks were invited?

How many poster presentations have you given?

What barriers have you come across when trying to attend conferences?

\section{3) Obtaining Funding:}

\section{a) Have you applied for Travel Grants?}

Yes Would like to Not thought about it No interest

If yes:

How many have you applied for?

How many have you been awarded?

\section{b) Have you applied for Project Grants?}

Yes Would like to Not thought about it No interest

If yes:

How many have you applied for?

How many have you been awarded?

c) Have you applied for a Fellowship?

Yes Would like to Not thought about it No interest 
If yes:

How many have you applied for?

How many have you been awarded?

5.4) `How many times have you have been named as a Co-applicant on a Grant application in:

a) 2005 :

b) 2006 :

c) 2007 :

If any of these applications were successful please give details of the funding body and the dates awarded:

5.5) 'How many times have you been the named researcher on a Grant application in:

a) 2005 :

b) 2006 :

c) 2007 :

If any of these applications were successful please give details of the funding body and the dates awarded:

6. 5.6) What are your future career plans?

Please tick the box that best represents your current plans. I plan to:

Stay in academia at Sheffield University

Stay in academia at another University

Work in the Science Industry

Work in the non-science sector

Retrain for another career

Become self-employed

Move abroad

Not sure

Other Please State:

If you plan to stay in academia, what direction would you like to take your career in?

5.7) Do you feel there is a career for you at the Medical School?

Yes No

Please explain your response:

6) Do you have any additional comments or issues about your experience of working in the Medical School.

7) What support would you like to receive from the University/Medical School, in terms of your career development?

The below section is optional, however you are encouraged to fill it in so that Dr Lucy Lee can contact you regarding any specific training or career development needs you may have: 
Name (optional):

Section (optional):

Email address (optional):

Thank you for taking the time to fill this in, please return this form to Dr Lucy Lee 